\title{
ПІДГОТОВКА УЧНІВ ДО ЖИТТЯ ЯК МЕТА УКРАЇНСЬКОЇ ПРОФЕСІЙНОЇ ОСВІТИ НА БУКОВИНІ (КІНЕЦЬ ХІХ - ПОЧАТОК ХХ СТ.)
}

Статтюо присвячено актуальній проблемі підготовки учнів до життя. Автори висвітлили досвід підготовки дітей та юнацтва до життя в професійних навчальних закладах Буковини (кінець ХІХ - початок XX ст.). Показано творчі здобутки буковинських педагогів, громадських та освітніх діячів на ниві розвитку теорії і практики української професійної, зокрема агрономічної, освіти. Прогресивні педагоги Буковини визначили мету й завдання, обьрунтували методи, форми й різні базові аспекти виховання господарської культури учнів. Уцвому вони вбачали один із ключових моментів підготовки випускника школи до практичного життя з огляду на соціальний склад населення краю (де переважало селянство), ментальність, народні традицї, спосіб господарювання українців тощо. Констатовано, що на Буковині була започаткована система неперервної агрономічної освіти, освітяни запропонували ефективні форми та методи просвітництва для юнаків та дівчат: тематичні лекції з кооперациї, сільськогосподарської, торговельної науки тоще. Украйнські громадські товариства краю («Руська бесіда», «Українська школа», численні жіночі товариства, «Взаймна поміч українського вчительства» та ін.) активно розвивали професійну освіту. Автори схарактеризували діяльність окремих навчальних закладів (українська реальна гімназія у Вашківиях, ткацька школа в Чернівиял, вища рільнича школа в Чернівиях, рільнича школа в Кіиямані), а також різнотермінові курси рахункового діловодства, крою $і$ шиття, господарські, кооперативні курси, народних промислів, ткацькі курси та ін. Початкові школи Буковини забезпечували процес формування практичних навичок учнів: викладання впродовж перших чотирьох років предмета "ручні роботи» для хлопців передбачало виготовлення навчальних приладів і предметів домашнього побуту та господарства; дівчата опановували ручні роботи: в'язання гачком і спицями, вишивання (хрестиком, гладюю) тощьо. У старших класах формували практичні вміння ремонту (латання) одягу, крою та шиття сорочок, прядіння, ткання на верстаті та ін.

Констатовано, щзо в сучасній освітній практиці доциільно творчо використати низку теоретичних $і$ практичних надбань діяльності українських громадських товариств на Буковині, здобутків педагогів краю щздо підготовки випускників шкіл, юнацтва до практичного життя.

Ключові слова: Буковина, підготовка до життя, учні, професійна освіта, агрономічна культура, рільнича школа.

Постановка проблеми. Актуадьність наукової розвідки визначається низкою суспільно-політичних, соціально-економічних, культурно-освітніх та науковотеоретичних чинників. Ідеться насамперед про відсутність дослідження проблеми підготовки дітей та юнацтва до життя в школах Буковини (кінець XIX - початок XX ст.). 3 одного боку, основні державні документи про освіту вказують на мету - формування

\footnotetext{
*(C) Білавич $Г$. B.

*(C) Слюсаренко Н. В.

*(C) Савчук Б. П.
}

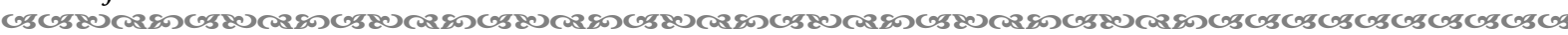


компетентностей, які б допомогли випускникові школи успішно адаптуватися до дорослого життя, з іншого боку, ще не окреслено ні цілісної наукової концепції цього процесу, також не розроблено моделі підготовки особистості до практичного життя. На жаль, нині немає і ефективних механізмів реалізації конкретних кроків з боку держави. Розв'язанню цих проблем може сприяти досвід виховання агрономічної культури дітей та юнацтва Буковини наприкінці XIX - на початку XX ст., коли громадянське суспільство, яке лише починало формуватися, зуміло мобілізувати національний потенціал та зорганізувати учнів до оволодіння знаннями, уміннями, навичками в галузі професійної, зокрема й агрономічної, освіти.

Аналіз досліджень. В українській науці є грунтовні праці в галузі історії розвитку освіти на Буковині за досдіджуваного періоду (В. Звоздецька $А$. Кобилянська, Д. Пенішкевич, І. Петрюк, Д. Тимчук та ін.), але наразі відсутне цілісне досдідження теорії і практики підготовки учнів до практичного життя в школах Буковині наприкінці XIX - на початку XX ст.

Мета статті - висвітдити основні напрями підготовки до життя дітей та юнацтва в професійних закладах Буковини (кінець XIX - початок XX ст.).

Виклад основного матеріалу. Попри те, що в освітньому просторі Буковини кінця XIX - початку XX ст. не було випрацювано в цілісному вигляді науковообгрунтованої концепції формування особистості, окремі напрями професійного навчання достатньо широко представлено в працях А. Андрохович, І. Герасимовича, I. Карбулицького, Д. Пігуляка, О. Поповича, С. Смаль-Стоцького та ін., які, до прикладу, 3-поміж іншого визначили мету й завдання, обгрунтували методи, форми й різні базові аспекти виховання господарсько-економічної культури дітей, юнацтва, дорослого населення. У цьому українські педагоги вбачали один із кдючових моментів підготовки випускника шкоди до практичного життя з огляду на соціальний склад наседення краю, ментальність, народні традиції, спосіб господарювання українців тощо. Розглянемо більш докладно окремі напрями й форми професійної підготовки учнів Буковини досліджуваного періоду.

Завдяки законам Австро-Угорщини 60-х pp. XIX ст., які декларували широкі демократичні свободи, зокрема закон про об'єднання та збори 1867 р., спочатку представники вищих прошарків суспільства, а згодом і вчительство, священики, службовці почали гуртуватися навколо широкої мережі різних товариств: 1870 р. на Буковині було 27 товариств [12] (за статистичними даними, станом на 1880 р. у краї налічувалося 170 товариств, серед яких кількість благодійних товариств - 34, казинотовариств - 17, читальних товариств - 14, музичних - 4; станом на 1905 р. загальне число товариств на Буковині зросло до 1530 [14]), однак більшість із них існували лише на папері.

На початку XX ст. провідні громадські й освітні діячі Буковини як пріоритетне завдання кваліфікували агрономічне просвітництво дітей та дорослих, започаткували систему неперервної агрономічної освіти, наголосили на важливості формування агрономічної культури особистості впродовж усього життя, запропонували ефективні форми та методи просвітництва, з-поміж яких: господарсько-економічні виклади (лекції) $з$ кооперації, господарської та торговельної науки. Просвітителі доносили до загалу українців ідею про те, що однією з умов подіпшення матеріального становища дюдей є здобуття фахової освіти. Важдивим шляхом до цього могла стати приватна освіта, розвиток якої регламентував Закон «Про приватну середню освіту» від 4 квітня 1911 р. Таку функцію виконувала перша українська агрономічна школа, відкрита 1871 р. за сприяння X. Петровича - президента Товариства крайової культури. 1895 р. ii реорганізовано в трирічну середню агрономічну школу [5, с. 138-139]. Проте через початок Першої світової війни, відсутність масового розуміння значення національної фахової освіти, інші суспільно-політичні й соціально-економічні чинники українська передова громадськість не змогла втілити в життя ці плани.

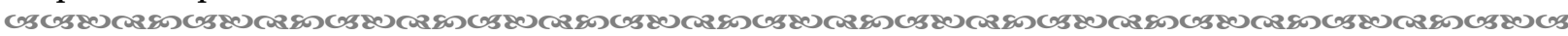
182 
У фарватері розвитку професійного шкільництва було громадсько-просвітницьке товариство «Руська Бесіда» у Чернівцях, яке виникло 26 січня 1869 р. «Руську бесіду» можемо слідом за «Просвітою» у Галичині (1868р.) назвати праматір'ю українських товариств на Буковині та точкою відліку, від якої розпочинається якісно новий етап у розвитку української освіти наприкінці XIX ст., започатковується система виховання агрономічної культури дітей та дорослих. Ці ідеї втілювали в життя освітні діячі, які гуртувалися в товаристві «Українська школа», метою якого було поширення освіти, зокрема й через відкриття приватних шкіл. Станом на 1914 р. «Українська школа» налічувала 12 філій. 1908 р. товариство започаткувало «Курс для подальшої освіти української молоді» в Чернівцях, який 1909 р. став приватною українською учитедьською дівочою семінарією з підготовчими курсами. За ініціативи громадського освітнього діяча І. Герасимовича 1912 р. у Вашківцях було засновано приватну українську реальну гімназію, яка давала українському юнацтву професійну освіту. Перед Першою світовою війною фахове шкільництво Буковини було державною справою, його презентували 14 державних середніх шкіл, що включали реальну гімназію, реальну школу, 3 жіночі ліцеї та 9 класичних гімназій, де навчалося 6617 учнів [5, с. 51, 120-140].

Буковинські педагоги ставили на порядок денний завдання - наблизити школу «до потреб нашого господарського життя», тому в удосконаленні господарського виховання в школі вбачався чинник, який міг докорінно «змінити становище української суспільності»: «спинити процес убожіння», забезпечити «систематичне скріплювання і усамостійнення нашого господарського організму... Перестати бідніти i зачати багатіти!» $[1$, с. 36$]$.

3 іншого боку, буковинські просвітителі наголошували на важдивості усвідомлення батьками досягнення мети виховання хлопця-господаря i дівчинигосподині, які в майбутньому передаватимуть свої знання, уміння вже власним дітям.

Наприкінці XIX ст. популярними в краї були професійні курси, які мали на меті забезпечити юнаків та дівчат фаховими знаннями й допомагати їм адаптуватися до міндивих суспільних обставин, поліпшити фінансово-економічне становище. Лідерами в організації цієї форми підвищення господарської культури стали «жіночі» товариства «Общество руських женщин», «Жіноча громада», «Кружок Жіночої громади» та ін. Так, з кінця XIX ст. до початку Першої світової війни діяли школи крою та шиття, курси «вищих робіт» (гаптування на шовку, художні артистичні вишивки, малювання на атласі); ручних робіт, виконаних за народними мотивами, для міської молоді; зимові господарські курси для сільської мододі; товариство «Жіноча громада» за міжвоєнного періоду XX ст. проводило двомісячні курси рахункового діловодства, крою i шиття; шеститижневі курси крою і шиття; тримісячні курси «Порадня практичного шиття i пристосування до нього народних вишивок», господарські (кооперативні) курси та медичної підготовки [9, с. 132-150].

1900 р. за сприяння української письменниці і педагога Є. Ярошинської організовано ткацькі курси для дівчат. Товариство православних русинок, що діяло на Буковині (1908-1921 рр.), сприяло не тільки масовій освіті українського жіноцтва, а й улаштовувало професійні курси і школи для юнаків, широкого загалу [7, с. 169].

1906 рік став знаковим у розвитку професійної освіти дия дівчат: за сприяння активних діячок товариства «Жіноча громада» (Чернівці) у місті відкрили ткацьку школу, де навчалося 12 учнів. 3 метою збереження та попуяяризації українського народного мистецтва художники, учителі, громадські діячі організували навчання дітей, навчали прийомів виготовлення художніх виробів тощо. До прикладу, учителька малювання К. Костецька разом із членами «Жіночої громади» збирала твори народного мистецтва, робила замальовки зі старих килимів та вишивок. Ці матеріали слугували зразками для навчання ткацтва в Чернівецькій ткацькій школі [9, с. 22]. Однак плідна діяльність школи була перервана подіями Першої світової війни, що наклало негативний відбиток на розвиток освіти і культури краю. Завдяки наполегливим us 183 
старанням художниць Є. Прибильської, О. Спаської, А. Середи, Є. Поленової 1916 р. було відновлено роботу ткацької школи і створено так звані загони трудової допомоги в майстернях, де працювало близько півтори тисячі буковинок. У квітні 1917 р. продукція цих майстерень експонувалася на виставках у Києві та Москві [7, с. 170-190].

Українська педагогічна думка того часу, з огляду на потреби практичного життя, окреслила коло якостей, які потрібно було виховати в дітей та юнацтва, задля підготовки їх до дорослого життя, а саме: працьовитість, господарність, ощадність, навички здорового способу життя, охайність, милосердя, доброчинність тощо. Розв'язання цих завдань ускдаднювало видове розмаїття господарсько-виховної діяльності. Воно мало чіткий поділ за гендерною і деякою мірою віковою ознаками та повсякчас наповнювалася новим змістом: до «традиційних» знань із сільського господарства (рослинництво, тваринництво, ветеринарія, садівництво, городництво тощо) і домашньо-побутової роботи (куховарство, швацтво, столярство й т. ін.) додалися кооперативні (організатор кооперації та підприємницької діяльності зі збереження, переробки, збуту, реалізації продукції тощо).

У початкових школах (як державних, так і приватних) передбачалося викдадання предметів «ручні роботи» («наука рукоділдя»), а також учні вивчали «науку природи», «землепис», що спрямовували на здобуття знань практичного характеру [15], проте залишалися відмінності щодо їх вивчення в різних типах закладів. У міських школах ручні роботи викладалися по 2 год. щотижнево в мододших (з 2 класу) та по 4 год. у старших класах. У сільських школах, де опановували третій і четвертий ступені народної освіти, ручні роботи запровадили лише в молодших класах [11], що було зовсім недостатньо для підготовки дітей до майбутнього самостійного життя.

3-поміж офіційних чинників існувало розуміння того, що рівень господарського виховання в початковій школі не відповідае соціальній структурі населення, зокрема Буковини, у плані підготовки дітей до праці в сільському господарстві та ремеслі. Дия розв'язання цієї проблеми в травні 1875 р., згідно з розпорядженням Крайової шкільної ради (КШР), для учнів народних шкіл запровадили т. зв. недільне навчання. Воно тривало з 15 до 17 год та ставило за мету надати сільським дітям «додаткові» теоретичні і практичні знання в галузях землеробства, тваринництва, хатнього господарства, «господарських рахунків», а міським - у сфері ремесла, промислу, торгівлі тощо [8, с. 89100]. За освітнім законодавством виділові та недільні доповнюючі школи мали озброювати учнів знаннями, необхідними для вступу до фахових шкіл та роботи в сільському господарстві, торгівлі, промисловості [13, с. 83]. Утім, вони лише частково розв'язували проблему практичної підготовки юнаків і дівчат. Українські педагоги і громадські діячі розуміли й критикували такий стан справ. Виступи освітян на сторінках часопису «Учитель» (Павдюк О. «Новий голос про доповняючу науку», 1908, ч. 4-5; А. Ш. «І ще дещо про доповнюючу науку», 1908, ч. 2; Наумович І. «Падіння народних шкіл і як би тому зарадити», 1869, ч. 37; та ін.) визначали шляхи і засоби поліпшення «доповнюючої науки». Педагоги вказували, що в сільській школі вивчається лише «рільничий напрям», який доцільно доповнити знаннями 3 інших галузей сільського господарства й ремесла. Стверджувалося, що вчителі обмежуються формальною подачею відомостей із сільського господарства, тож не формують в учнів відповідних практичних навичок. Автори пропонували розширювати «науку рільництва», надавати школярам знання 3 бджільництва, шовківництва, інших промислів, які згодом можуть принести реальні доходи для сільських хліборобів.

Порівняно з іншими західноукраїнськими землями, на Буковині наприкінці XIX на початку XX ст. складися сприятдиві умови для господарського навчання і виховання дітей, де у 216 українських народних школах навчалося близько 40 тис. учнів, тобто абсодютна більшість дітей шкільного віку [5, с. 120-140]. Викладання впродовж перших чотирьох років предмета «ручні роботи» для хлопців передбачало виготовлення навчальних приладів і предметів домашнього господарства. Дівчата опановували ручні us 184 
роботи як складник домашнього господарства: в'язання гачком і спицями, мереження, вишивання (хрестиком, гладдю) тощо. У старших класах формували уміння ремонту (латання) одягу, крою та шиття сорочок, прядіння, ткання на верстаті [10].

Для прищеплення сільськогосподарських знань, формування умінь і навичок при народних школах Буковини створювалися пришкільні городи та дослідницькі ділянки. Принципи і зміст їх функціонування відображає «Підручник у справах шкільних» I. Герасимовича (1914р.). Особлива увага зверталася на організацію індивідуальних і групових форм агрономічної освіти відповідно до вікових і статевих особливостей школярів. Підкреслювалося, що «Плеканє шкільного огороду і газдованє на досвіднім поли» входить до компетенції керівництва школи, яке могло б залучати до цієї роботи різних фахівців [2, с. 36-70].

За довоєнного періоду XX ст. на Буковині українська державна професійна освіта досягла високого рівня розвитку, профільний характер якої зумовлювався соціальноекономічними потребами краю. Так, за відносно сприятливих суспільно-політичних умов вона стала свого роду викдиком нерозумінню значення модерних агрономічних знань більшістю населення краю [4]. Покликаючись на приклад інших етнічних груп, українці Буковини домоглися відкриття в жовтні 1871 р. власної сільськогосподарської школи в Чернівцях, яка 1895 р. набула статусу середнього освітнього закладу із трирічним терміном навчання [3, с. 86]. На нашу думку, про іiі високий рівень засвідчують вимоги до педагогічного складу (суворий конкурсний відбір; запрошення осіб із науковим ступенем) та до прийому учнів (закінчення чотирьох класів гімназії чи реальної школи; свідоцтво про «моральний стан» тощо). Випускники школи мали «довести знання з фізики, рільничої хімії, описової геометрії, з основ поміру полів та кліматологї», а також «з анатомії і фізіології домашніх тварин, технології лісничої хімії, лісничого креслення, планування, масштабування»; вони мали право вступу до сільськогосподарської чи лісотехнічної академій. Зміст навчання становили профільні та професійно орієнтовані загальноосвітні предмети [3].

Попри належне матеріально-технічне й фінансове забезпечення, кількість охочих здобувати освіту в чернівецькій агрошколі зменшувалася, що пояснювалося не стільки високою платнею за навчання, скільки незатребуваністю фахівців високої кваліфікації, позаяк неорганізоване українське селянство краю не могло в індивідуадьному порядку сплачувати їхні послуги, а головне - не було готове вносити інновації в традиційну систему господарювання. Більш популярною стала дворічна рільнича школа 3 українською мовою навчання в Кіцмані, яка давала «нижчу» фахову освіту, орієнтовану на потреби загалу дрібного селянства. Про це свідчить їі мета - підготувати «мужицьких синів», «щоби вони селянську господарку самостійно раціонально могли вести» [6].

Рільнича школа в Кіцмані була створена за найкращими европейськими зразками, готувала зразкових господарів, у процесі підготовки кадрів ураховувала специфіку краю: поряд зі знаннями з ведення домашнього господарства, агрономії, ветеринарії, надавала юнацтву знання в галузі садівництва тощо. У школі, заснованій Буковинським Соймом 1 лютого 1895 р. (відкритій 13 жовтня 1897 р.), першого року навчалося 8 учнів. Вона задоводьняла освітні потреби українців - рідною мовою, німців - німецькою мовою. Тут вивчали не лише теоретичні науки, але й проводили «практичну взірцеву господарку в галузях, потрібних для місцевих мешканців» [6]. Школа в Кіцмані була своєрідним навчально-виробничим комплексом, з розвиненою як на той час матеріальною базою, необхідною для підготовки учнів до практичного життя, виховання в них агрономічної культури. Зокрема, тут були необхідні навчальні приміщення; майстерня, бібліотека; «для ведення взірцевої господарки» школа мала поле в розмірі 17,5 га; дерев' яну стайню 3 мурованою молочарнею й коморою для приготування поживи худобі; дерев'яний курник; численні господарські приміщення; стайню для овець; курник; дровітню, комору, криницю; ведике чотирикутне подвір'я з квітниками й закладеним молодим садом (яблуні, груші, сливи, вишні, черешні) та виноградником, площею 3 а; поле для

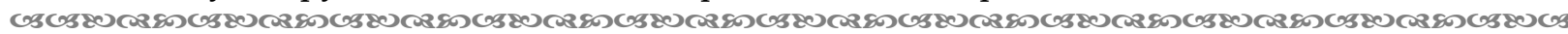
185 
вирощування сільськогосподарських культур було поділено на низку ділянок для переміни сівби (тут вирощували корм для худоби), а також засівали пшеницю, жито, ячмінь, овес, кукурудзу, картоплю, буряки, а також саджанці. Окрім рослинництва, садівництва, вирощували тваринництво, була пара коней; 1 бугай, 9 корів, 5 шт. мододняка (молоко використовували здебільшого в інтернаті, а надлишок продавади); 3 свиней; 5 овець. Доглядали худобу по черзі учні» [6].

Типовий зміст професійної освіти ілюструе Кіцманська рільнича школа, де викладали широкий перелік загальноосвітніх та фахових дисциплін (фізика, хімія, мінеродогія, законодавство, релігія, рідна та німецька мови, арифметика, геометрія, міряння поля, рисунки, наука про землю, географія, історія, «натуральна історія» (природознавство), бджільництво, «наука про будову рослин» (ботаніка), «наука про продуктивність звірят» (зоологія), «наука властивої господарки» (сільське господарство), «наука про удержання здоров'я звірят» (ветеринарія), «наука лісового господарства», загальна і спеціальна культура рослинної та тваринної продукції, книговедення, ведення господарки, вирощування ярини, городини), а також гімнастика, мадювання, співи. Практичні заняття проводилися за окремими бдоками: вирощування овочів і фруктів; обробка землі; догляд за свійськими тваринами; переробка молока; праця на сільськогосподарських знаряддях і машинах; ведення бухгалтерії тощо [там само]. Як бачимо, широкий спектр загальноосвітніх та фахових дисциплін, а також блок практичної підготовки забезпечували високий професійний рівень іiі випускників. Юнаки оволодівади знаннями і навичками з різних ремесел: садівництва, столярства, різьбярства, кошикарства, римарства.

Висновки. Отже, зважаючи на соціальний склад населення Буковини, де селянство на початку XX ст. становило близько $90 \%$, розвиток фахової сільськогосподарської освіти виступив важливим чинником його життєдіяльності. Утім, держава не могла забезпечити їі належного рівня, тож за відсутності рідномовних шкіл українство взяло курс на створення альтернативної системи позашкільної освіти, що відіграло вагому родь у вихованні господарської культури дітей та юнацтва. Українські громадські товариства вагомо спричинилися до організації агрономічної освіти дітей, юнацтва та дорослого населення, організації фахової освіти.

Перебування Буковини за досліджуваного періоду у складі Австро-Угорщини певним чином позначилося на ролі й значенні державного шкільництва в підготовці дітей та юнацтва до практичного життя. Наприкінці XIX - на початку XX ст. у краї сформувалася багатоступенева система освіти, яку представляли різні типи навчальних закладів. Зростає роль практичної підготовки дітей та юнацтва до життя, актуалізується значення господарського навчання i виховання, організаційно-методичного рівня забезпечення цього процесу. Розгортання діяльності в цій ділянці супроводжувалося дискусіями в освітянському середовищі та активними творчими пошуками українських педагогів щодо успішної підготовки дітей та юнацтва до життя.

У сучасній освітній практиці доцільно творчо використати низку теоретичних і практичних надбань діяльності українських громадських товариств на Буковині, здобутків педагогів краю щодо підготовки випускників шкіл до практичного життя, формування господарської культури особистості.

Подальших наукових пошуків вимагає питання навчально-методичного забезпечення української професійної освіти Буковини наприкінці XIX - на початку XX ст.

\section{Список використаних джерел:}

1. Білавич Г. Теорія і практика виховання господарської культури учнів та дорослих у Західній Україні (друга половина XIX - початок 40-х рр. XX ст.). Івано-Франківськ: НАIP, 2015. 740 с.

2. Герасимович I. Підручник в справах шкільних: Збірка шкільних законів і розпорядків. Заставна: 3 друк. Товариства «Руська Рада», 1914. 364 с. 
3. Карбулицький I. І. Розвій народного шкільництва на Буковині. Вашківці: 3 друк. Тов. «Руська Рада», 1905. 148 с.

4. Краєва середня господарська школа в Чернівцях. Буковина. 1897. Ч. 136. С. 1-2.

5. Пенішкевич О. Розвиток українського шкільництва на Буковині (XVIII - початок XX ст.): монографія. Чернівці: Рута, 2002. 520 с.

6. Рільнича школа в Кіцмані. Буковина. 1897. Ч. 140. С. 2-5.

7. Савчук Б. Жіноцтво в суспільному житті Західної України: остання третина XIX ст. - 1939 р. Івано-Франківськ: Ділея-НВ, 1998. 278 с.

8. Ступарик Б. Шкільництво Галичини (1772-1939). Івано-Франківськ, 1994. 144 с.

9. Тимчук А. І. Організаційно-педагогічні засади української освіти дорослих на Буковині (18691940 рр.): дис... канд. пед. наук: 13.00.01. Івано-Франківськ: Прикарпатський національний університет імені Василя Стефаника, 2005. 230 с.

10. Трусевич М. Наука жіночих ручних робіт в народній школі. Bukowiner Schule. 1907. Ч. 7. C. 242-246.

11. Школи дівочі. Учитель. 1869. Ч. 32. С. 125-126.

12. Geschribene Photographien von Czernowitz. Czernowitzer Zeitung. 1870. № 27. 18. Februar. P. 2.

13. Szematyzm Galicji i Lodomeryi wraz z Wielkim Ksiestwem Krakowskim na rok 1890. Lwów, 1914. S. 83.

14. Vereine in der Bukowina. Bukowiner Post. 1907. № 2017. 8. Jänner. P. 1.

15. Zarys organizacyi szkol nizszych / Skreslil B. Trzaskowski. Lwow: Nakladem awtora, 1867. $60 \mathrm{~s}$.

\section{References:}

1. Bilavych, H. (2015). Teoriia i praktyka vykhovannia hospodarskoi kultury uchniv ta doroslykh u Zakhidnii Ukraini (druha polovyna XIX - pochatok 40-kh rr. XX st.) [Theory and practice of economic culture of students and adults in Western Ukraine (second half of the XIX - early 40's of the twentieth century)]. Ivano-Frankivsk: NAIR [in Ukrainian].

2. Herasymovych, I. (1914). Pidruchnyk v spravakh shkilnykh: zbirka shkilnykh zakoniv [Textbook in school affairs: a collection of school laws]. Zastavna: Ruska Rada [in Ukrainian].

3. Karbulytskyi, I. I. (1905). Rozvii narodnoho shkilnytstva na Bukovyni [Development of public schooling in Bukovyna]. Vashkivtsi: Ruska Rada [in Ukrainian].

4. Kraieva serednia hospodarska shkola $\mathrm{v}$ Chernivtsiakh [Regional secondary economic school in Chernivtsi]. (1897). Bukovyna, 136, 1-2 [in Ukrainian].

5. Penishkevych, O. (2002). Rozvytok ukrainskoho shkilnytstva na Bukovyni (XVIII - pochatok XX st.): monohrafiia [Development of Ukrainian schooling in Bukovyna (XVIII - early XX century): monograph]. Chernivtsi: Ruta [in Ukrainian].

6. Rilnycha shkola v Kitsmani [Agricultural school in Kitzman]. (1897). Bukovyna, 140, 2-5 [in Ukrainian].

7. Savchuk, B. (1998). Zhinotstvo v suspilnomu zhytti Zakhidnoi Ukrainy: ostannia tretyna XIX st. 1939 r. [Women in public life of Western Ukraine: the last third of the XIX century - 1939]. IvanoFrankivsk: Lileia-NV [in Ukrainian].

8. Stuparyk, B. (1994). Shkilnytstvo Halychyny (1772-1939) [Schooling in Galicia (1772-1939)]. IvanoFrankivsk [in Ukrainian].

9. Tymchuk, L. I. (2005). Orhanizatsiino-pedahohichni zasady ukrainskoi osvity doroslykh na Bukovyni (1869-1940 rr.) [Organizational and pedagogical principles of Ukrainian adult education in Bukovyna (1869-1940)]. (Candidate's thesis). Vasyl Stefanyk Precarpathian National University. Ivano-Frankivsk [in Ukrainian].

10. Trusevych, M. (1907). Nauka zhinochykh ruchnykh robit $\mathrm{v}$ narodnii shkoli [The science of women's handicrafts in public school]. Bukowiner Schule,7, 242-246 [in Ukrainian].

11. Shkoly divochi [Girls' schools]. (1869). Uchytel, 32, 125-126 [in Ukrainian].

12. Geschribene Photographien von Czernowitz [Written photographs of Chernivtsi]. (1870). Czernowitzer Zeitung, 27, 2 [in German].

13. Szematyzm Galicji i Lodomeryi wraz z Wielkim Ksiestwem Krakowskim na rok 1890 [The Szematism of Galicia and Lodomerya with the Grand Duchy of Kraków for 1890]. (1914). Lwów [in Poland].

14. Vereine in der Bukowina [Associations in Bukovina]. (1907). Bukowiner Post, 2017, 1 [in German].

15. Zarys organizacyi szkol nizszych [Outline of the organization of lower schools]. (1867). Lwow: Nakladem awtora [in Poland]. 
Bilavych H. $V$., orcid.org/0000-0002-1555-0932

Slyusarenko N. V., orcid.org/0000-0002-9215-5936

Savchuk B. P.,

PREPARING STUDENTS FOR LIFE AS A PURPOSE OF UKRAINIAN PROFESSIONAL EDUCATION IN BUKOVYNA (END OF XIX - EARLY XX CENTURY)

The article is devoted to the topical problem of preparing students for life. The authors highlighted the experience of preparing children and youth for life in vocational schools in Bukovyna (late XIX - early XX century). The creative achievements of Bukovynian teachers, public and educational figures in the field of development of the theory and practice of Ukrainian professional education, in particular agronomic, are shown. Progressive teachers of Bukovyna defined the purpose and tasks, substantiated methods, forms and various basic aspects of education of students' economic culture. They considered this as one of the key moments in preparing a school graduate for practical life, given the social composition of the region's population (dominated by the peasantry), mentality, national traditions, etc. A system of continuous agronomic education was launched in Bukovyna, and educators proposed effective forms and methods of education for young men and women: thematic lectures on cooperation, agriculture, trade, etc. Ukrainian public associations of the region («Ruska Besida», «Ukrainska Shkola», numerous women's associations, Mutual Assistance of Ukrainian Teachers, etc.) actively developed professional education. The authors described the activities of some educational institutions (Ukrainian real gymnasium in Vashkivtsi, weaving school in Chernivtsi, higher agricultural school in Chernivtsi, agricultural school in Kitsman), as well as various courses in accounting, tailoring and sewing, economic, cooperative, folk crafts courses, etc. Primary schools in Bukovyna ensured the process of forming students' practical skills: teaching the subject "handicrafts» for boys during the first four years involved the manufacture of teaching aids and household items and household items; the girls mastered handicrafts: crochet and knitting, cross-stitch, etc. In the senior classes they formed practical skills of repairing (patching) clothes, cutting and sewing shirts, spinning, weaving on a machine, etc.

In modern educational practice, it is advisable to creatively use a number of theoretical and practical achievements of Ukrainian public societies in Bukovyna, the achievements of teachers in the region regarding preparing school graduates and youth for practical life.

Key words: Bukovyna, preparation for life, students, professional education, agronomic culture, agricultural school. 